\title{
THE INFLUENCE OF ENTREPRENEURIAL CULTURE ON ENTREPRENEURIAL INTENTION AMONG BUSINESS STUDENTS
}

\author{
Genoveva \\ Email : genoveva@president.ac.id \\ Management Study Program, Business Faculty, President University, \\ Bekasi, Indonesia
}

\begin{abstract}
The number of entrepreneurs in Indonesia increased in 2017 from $1.67 \%$ to $3.10 \%$ from 225 million Indonesians. But the number is still less than the number of our neighboring entrepreneurs, Malaysia has $6 \%$ entrepreneurs, Singapore $7 \%$ and Thailand 5\%. Increasing the number of entrepreneurs shows the increasing economic growth of a country, therefore the government made various efforts encourages the growth of the number of entrepreneurs in Indonesia, through education in this case the ministry of education provides an appeal for entrepreneurship to be included as part of the curriculum, both at the high school and university level. Entrepreneurship education giving the students experiances of various technical and skills to become more confident as an entrepreneurs. Beside of education, motivation, personality and family background also determine entrepreneurial intention. The aims of this research is to find out the entrepreneurial education, entrepreneurial motivation, entrepreneurial personality and family background influence on entrepreneurial intention. This study uses a sample of 326 business students of President University. The data collection using google docs that is spreaded via whatshapp, line and email. The result of the study were processed using SPSS version 22. The conclusion show that independent variables (entrepreneurial education, entrepreneurial motivation, entrepreneurial personality and family background) influence on entrepreneurial intention with affected $54.4 \%$ and the rest by the others factors.
\end{abstract}

Keywords: Entrepreneurial culture, entrepreneurial education, entrepreneurial motivation, entrepreneurial personality, family background, entrepreneurial intention.

\begin{abstract}
Abstrak
Jumlah pengusaha di Indonesia meningkat pada 2017 dari 1,67\% menjadi 3,10\% dari 225 juta orang Indonesia. Tetapi jumlahnya masih kurang dari jumlah pengusaha tetangga kita, Malaysia memiliki $6 \%$ pengusaha, Singapura 7\% dan Thailand 5\%. Meningkatnya jumlah wirausahawan menunjukkan meningkatnya pertumbuhan ekonomi suatu negara, oleh karena itu pemerintah melakukan berbagai upaya mendorong tumbuhnya jumlah wirausaha di Indonesia, melalui pendidikan dalam hal ini kementerian pendidikan memberikan imbauan agar kewirausahaan dimasukkan sebagai bagian kurikulum, baik di tingkat sekolah menengah dan universitas. Pendidikan kewirausahaan memberi siswa pengalaman berbagai teknik dan keterampilan untuk menjadi lebih percaya diri sebagai wirausaha. Selain pendidikan, motivasi, kepribadian dan latar belakang keluarga juga menentukan niat wirausaha. Tujuan dari penelitian ini adalah untuk mengetahui pengaruh pendidikan wirausaha, motivasi wirausaha, kepribadian wirausaha dan latar belakang keluarga terhadap niat berwirausaha. Penelitian ini menggunakan sampel 326 mahasiswa bisnis President University. Pengumpulan data menggunakan google docs yang disebarkan melalui whatshapp, line, dan email. Hasil penelitian diolah menggunakan SPSS versi 22. Kesimpulannya menunjukkan bahwa variabel independen (pendidikan kewirausahaan, motivasi wirausaha, kepribadian wirausaha dan latar belakang keluarga) mempengaruhi niat berwirausaha dengan pengaruh $54,4 \%$ dan sisanya oleh faktor lain.
\end{abstract}




\section{Kata kunci: $\quad$ Budaya wirausaha, pendidikan kewirausahaan, motivasi wirausaha, kepribadian} wirausaha, latar belakang keluarga, niat wirausaha.

\section{A. Research Background}

The number of entrepreneurs in Indonesia increased in 2017 from $1.67 \%$ to $3.10 \%$ from 225 million Indonesians (BPS, 2018). But the number is still less than the number of our neighboring entrepreneurs, Malaysia has 6\% entrepreneurs, Singapore 7\% and Thailand 5\%. The others country in Asia also increased in 2017, such as China $10 \%$ and Japan $11 \%$. Increasing the number of entrepreneurs shows the increasing economic growth of a country (Ndofirepi \& Rambe, 2016). The contribution of entrepreneurs of a country is vital because it has direct imact to economic development (Baron \& Shane, 2008), therefore the government made various efforts in increasing the number of entrepreneurs in Indonesia, such as the ease of regulation of business permits, the provision of business loans with low interest rates, business facilities for micro business and entrepreneurship education.

The Indonesian government strongly encourages the growth of the number of entrepreneurs in Indonesia, through education in this case the ministry of education provides an appeal for entrepreneurship to be included as part of the curriculum, both at the high school and university level (Indonesia Ministry of Education, 2018). Entrepreneurship education giving the students experiances of various technical and skills to become more confident as an entrepreneurs (Chen et al, 2010).

The students experianced develop besides supported by education curriculum, creation of entrepreneurship culture is also influenced by personality factor, motivation and family background (Echecopar et all, 2011). The selection of students to study in business field also influence to students in business intention (Maresh, 2016). In relation, since President University design the curriculum that included entrepreneurship as the subject to all of study program and also Corporate Entrepreneur and Business Start Up to Business Faculty students, some of the students continue their business project as the real business because of their interesting of business. The corporate entrepreneur subject also build the students character, mindset and spirit as a manager in company / organization. A business students should be have a passion to become entrepreneurs, but based on survey results only about 4.17\% (President University, 2018) business school students who become entrepreneurs. The low number of alumni who become 
entrepreneurs encourages Management President University to change the curriculum that is more entrepreneurial entrusted, where students are taught from the formation of character to entrepreneurship until to create the business plan and also practice it with the support of the business incubator provided by the campus. Based on this background, researcher interested to know the influence of entrepreneurial culture on entrepreneurial intention among business students of President University, Indonesia.

\section{B. Literature Review}

\section{Entrepreneurship}

Entrepreneurship is the act of creating a business or businesses while building and scaling it to generate a profit. (Galvao et al, 2018). However, as a basic entrepreneurship definition, it's a bit limiting. The more modern entrepreneurship definition is also about transforming the world by solving big problems. Like initiating social change creating an innovative product or presenting a new life-changing solution.

According to Hisrich et al (2018) entrepreneurship is a dynamic process of creating wealth, and the process of creating something new that has value by devoting the time and effort required, taking risks financial, psychological and social, and obtain results in the form of finances, personal satisfaction and freedom. Entrepreneurship can occur in all areas (Hisrich et al, 2018). This needs to be measured for Entrepreneurship can also directly influence business performance. In the sense entrepreneurship is not only for purely trade event, but in the there are many entrepreneurial traits and characters that arise and canstudied . Characters that exist among others :

1. Independent and honest

2. Have business professionalism

3. Discipline, initiative, creative

4. Oriented achievements and future

5. Resilient, optimistic and responsible

The other definition subscribe entrepreneurship is defined as an activity that involves the discovery, evaluation and exploitation of opportunities to introduce new goods and services, 
ways of organising, markets, processes and raw materials through organising efforts that previously had not existed (Shane \& Venkataraman, 2000).

\section{Entrepreneurial Culture}

The concept of "entrepreneurial culture" has existed for decades, described as an organizational culture embodying and championing entrepreneurial characteristics and attributes. These have included risk-taking, innovation, and creativity; the elements one would expect to see among entrepreneurs as individuals (Wong, 2014). The literature suggests that entrepreneurial culture is related to a number of positive organizational outcomes, such as generating new business and improving firm performance.

The entrepreneurial culture influencing of personality, motivation and family background beside of curriculum. Students bring to university their personality and family backgrounds as well as their personal motivations regarding entrepreneurship. The university provides a specific context of curriculum, rules, expectations and norms of behavior that also contributes to shape the student's attitude on entrepreneurial interntion (Echecopar et all, 2011).

\section{Entrepreneurial Education}

Entrepreneurship education generally contains materials and activities related to building an entrepreneurial mental attitude, practicing communication skills, building networks and devising profit-oriented business plans. The most appropriate faculty or study program requires that students follow entrepreneurship courses are the faculty of economics or business (Susilaningsih, 2015).

Entrepreneurship is defined as "creating something new with value by devoting necessary time and effort, assuming the accompanying financial, psychic and social risks and receiving the resulting rewards of monetary and personal satisfaction of independence” (Hisrich et al ,2018). Based on this definition, to solve graduate unemployment problem to overcome the graduates is to become an entrepreneur. In the other words, that is crucial to produce more graduate entrepreneur and important to promote entrepreneurship education, through the development of entrepreneurial activity among students (NabiI \& Linan, 2011). One of the role of entrepreneurship education should be help students to consider starting business as one of career alternatives, and develop positive attitudes on entrepreneurship (Fayolle \& Gailly, 2008). 
Research seems to suggest that people that attend to entrepreneurship courses have a higher propensity to start their own businesses at some point in their career (Jaafar \& Aziz, 2008).

\section{Entrepreneurial Motivation}

Motivation for entrepreneurship is complex and involves the dynamic interaction of factors (Nabi, Holden \& Walmsley, 2006). The most important and traditional entrepreneurial motivation is to get money. In its development, money is not the only reason why people as an entrepreneur, many other factors such as the desire to create jobs, provide social benefits for others, practice the knowledge that is obtained maximally, desire for achievement and various other motivations. Different scholars and researchers understand entrepreneurship differently and have come up with different and conflicting conclusions about how to boost and harness it for development. Motivation of entrepreneurship, it takes fighting power to succeed, willing to learn to see the success of others, has a strong urge to overcome all obstacles in entrepreneurship. Entrepreneurial motivation arises because there is a desire to achieve (Nugraha, 2016). The more convinced the meaning of his achievement, the more convinced that achievement must be able to push for a better achievement. In the motivation of entrepreneurship, it takes fighting power to succeed, willing to learn to see the success of others, has a strong urge to overcome all obstacles in entrepreneurship.

McClelland (2000) said the main psychological drivers that motivate entrepreneurs are the need for achievement, which is usually identified as need of achevement this need is defined as desire or encouragement in a person who motivates behavior on achieving goals (Sumarsono, 2010).

McClelland (2000) identified a correlation between the behavior of people who have high achievement motives and entrepreneurial behavior. Entrepreneurial behavior that is manifested in attitudes and motivation on a successful career and achievement, is reflected in the following actions:

1. Exemplify successful people in the same field of work, adapting techniques to achieve success

2. Use change to motivate yourself

3. Action-oriented

4. High responsibility for the success of an activity

5. Success is determined by the achievement of human data sources in the company 
6. Supervise so that decisions are carried out properly and do not regret past failures.

\section{Entrepreneurial Personality}

Several studies disscussed that personality is the combination of some characteristic. Sesen (2013) in entrepreneurial intention research describes entrepreneurial personality is individual factors, included locus of control and entrepreneurial self efficacy. While Ahmad et al (2010) said that personality is how to the person recognise and work on own shortcomings, maintain a high level of energy, respond to constructive criticism, prioritise tasks to manage time, manage own career development, motivate myself to function at an optimum level of performance, identify strengths and weaknesses and match them with opportunities and threats.

Yan (2010) concluded that entrepreneurail personality has an impact on entrepreneurial intention. personality measured by Yan in his research included the characteristics of traits, demographic factors, values and beliefs.

\section{Family background}

Joseph states that some form of family background proves to be integral in a child's development. Oftentimes, this involvement begins at birth and ends when the child graduates from high school. The American School Counselor Association commissions school counselors to provide support to their students and their families in specific areas. This section on family involvement reviews (a) family involvement in academic concerns, (b) family involvement in personal/social growth, and (c) family involvement in career development and the research that supports those areas (Joseph, 2012).

Family background refers to all the conditions and circumstances in the family which influence the child emotionally, physically, and intellectually (Muola, 2010). Children are coming from different family backgrounds that are affected differently by different family conditions, that's why some children have good family background while some have poor background. Citing Kirkwood, noted that with some families, the background way varies from time to time for the same individuals (Kirkwood, 2009). 
A family could also be categorized as nuclear and extended. The extended families are those family in which have a large group of related kin or in other words is the parents and children that live together in the same household. This is the type of families common in African countries. And nuclear family is the family where married couple lived together with their children. This type of family is commonly found in Western countries (Ugwuja, 2010) .

\section{Entrepreneurial Intention}

Entrepreneurial intention is an individual's intention has proven to be the best indicator of entrepreneurial behavior (Tang, 2007) . Entrepreneurial intentions also influence the actions of existing organizations. In established firms, as a result of intentional processes, individuals pursue and exploit opportunities (Stevenson \& Jarillo, 1986).

The research of Fiet (2014) concluded that entrepreneurship education in the form of courses is correlated to entrepreneurial intentions for three reasons. First, entrepreneurship education helps the students to learn and identify new business opportunities. Second, research found positive correlation between family background and intrepreneurial intention. While the important role of family business is introduce business to the next generation as early as possible. Third, culture has a correlation with entrepreneurial intention, a certain cultures familiarize their people to play a role in entrepreneurship. From the description it can be marked, an entrepreneurial intention is a central element in the evolving and sometimes long process of venture creation (Alain \& Benoit, 2008).

We can concluded that entrepreneurial intentions is the central element in the evolving and sometimes long process of venture creation achieve the goals of forming a business (Alain \& Benoit, 2008).

Based on the background and literature review of the research above, the hyphotesis of this study are :

H1 : Entrepreneurship education has influence on entrepreneurial intention among business students.

H2 : Motivation has influence on entrepreneurial intention among business students.

H3 : Personality has influence on entrepreneurial intention among business students.

H4 : Family background has influence on entrepreneurial intention among business students ? 
H5 : By simultaneously the entrepreneurship education, motivation, personality and family background have influence on entrepreneurial intention among business students.

\section{Methodology}

This research is quantitative research using a questionnaire as a method of data collection, where the questionnaire is distributed online by using Google docs. By using Slovin formula (Ryan, 2013) the number of respondents needed in this study is at least 319 respondents. The researcher collected 326 complete questionnaires therefore they could be processed in their entirety. Data was obtained using SPSS version 22 for descriptive analysis and multiple regression.

Figure 1 represents the theoretical framework of this research. Students bring to university their personality and family backgrounds as well as their personal motivations regarding entrepreneurship. The university provides a specific context of curriculum, rules, expectations and norms of behavior that also contributes to shape the student's attitude on entrepreneurship.

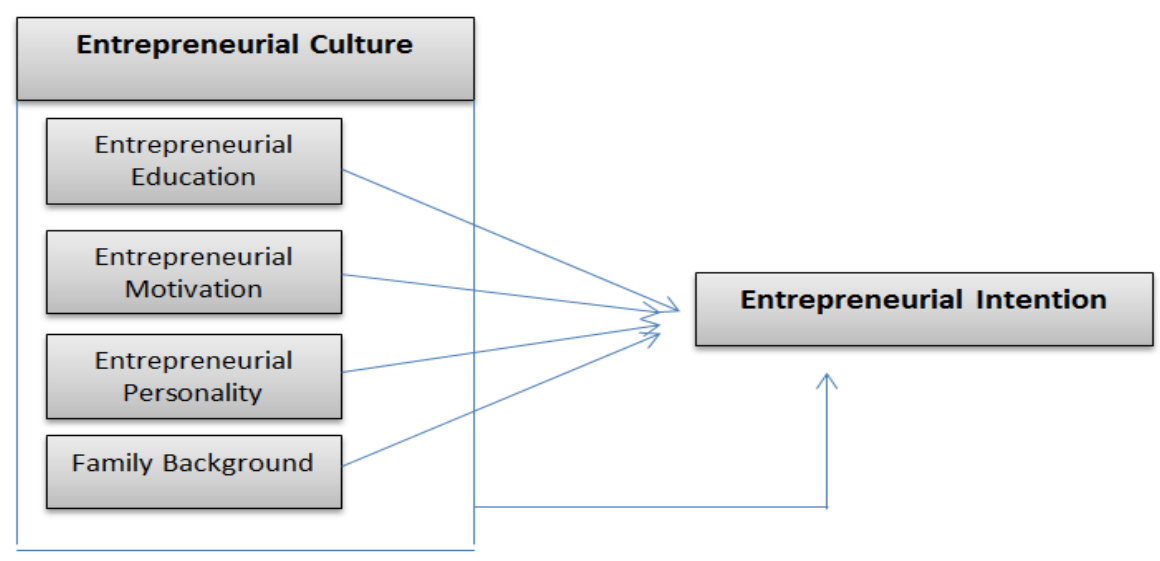

Figure 1 : Theoritical Framework

Source : Echecopar et all, 2011

\section{Conclussion and Discussion}

Respondents Profile 
The respondents profile show that (table 1) they are 54\% (176 respondents) are male and the rest are female 46\% (150 respondents). By study program, the table 1 shown that, mostly the study program of respondents are Management with total 55\% (181 respondents), then Accoounting are 24\% (78 respondent) and the last is administration Business are 67 respondents (21\%). Just $29 \%$ respondents having the family busines and the rest $71 \%$. (232 respondents).

Tabel 1 : Respondents Profile

\begin{tabular}{|l|c|c|}
\hline \multicolumn{1}{|c|}{ Profile } & Percentage (\%) & Total \\
\hline Gender : & $54 \%$ & 176 \\
Male & $46 \%$ & 150 \\
Female & $24 \%$ & 78 \\
\hline Study Program : & $21 \%$ & 67 \\
Accounting & $55 \%$ & 181 \\
Business Administration & & \\
Management & $29 \%$ & 94 \\
\hline Have a Family Business : & $71 \%$ & 232 \\
Yes & \\
No & \multicolumn{2}{|c|}{} \\
\hline
\end{tabular}

Source : Questionnaire, 2018

\section{Validity and realibility test}

The indicators of each variable consist of 8 questions, therefore the total questions are 48 . Researcher used 30 respondents for tested of validity and reliability. Researcher tested the validity based on the Pearson Correlation table with $\mathrm{R}$ score 0.361 . The result of variable Entrepreneurship Education, Personality and Entrepreneurial Intention are valid for all of questions because all of result bigger than 0.361. For variable Motivation and Family Background, each of them has 6 questions valid and 2 questions invalid because of the result less than 0.361 .

The reliability test results show that (Table 2) all the outcome variables are reliable because they have results above 0.600 (Maholtra, 2012). The variable that has the best reliability results (Perfect) is Entrepreneurial Intention, while 3 variables, namely Entrepreneurial Motivation, Entrepreneurial Personality and Family Background have high results and 1 variable namely Entrepreneurial Education is moderate. 
Tabel 2 : Reability Result

\begin{tabular}{|c|c|c|c|c|}
\hline Nariable & Questions & $\begin{array}{c}\text { Cronbach's } \\
\text { Alpha }\end{array}$ & $\begin{array}{c}\text { Internal } \\
\text { Consistency }\end{array}$ & Result \\
\hline Entrepreneurial Education & 8 & 0.626 & Moderate & Reliable \\
\hline Entrepreneurial Motivation & 6 & 0.839 & High & Reliable \\
\hline Entrepreneurial Personality & 8 & 0.841 & High & Reliable \\
\hline Family Background & 6 & 0.897 & High & Reliable \\
\hline Entrepreneurial Intention & 8 & 0.938 & Perfect & Reliable \\
\hline
\end{tabular}

Source : Questionnaire, 2018

\section{Descriptive Analysis}

Table 3 is representing the mean and SD (Standard Deviation) of each family business ownership. All of variables from respondents that have a Family Business higher than do not have Family Business respondents. The highest value of mean come from Family Background with mean value 4.434, and followed by Motivation (4.164), Personality (4.122) and Entrepreneurial education.

While respondents who do not have a Family Business with higher mean is personality with 4.075, then followed by Motivation with mean value 4.013, the next Entrepreneurial education with value 3.981, Entrepreneurial Intention with mean value 3.872 and last Family Background (3.565).

Table 3 : Family Business Descriptive Analysis

\begin{tabular}{|l|c|c|c|c|}
\hline \multirow{2}{*}{ Variable } & \multicolumn{2}{|c|}{$\begin{array}{c}\text { Have a Family } \\
\text { Business }\end{array}$} & $\begin{array}{c}\text { Don't have Family } \\
\text { Business }\end{array}$ \\
\cline { 2 - 5 } & Mean & SD & Mean & SD \\
\hline Entrepreneurial Education & 4.112 & 0.514 & 3.981 & 0.578 \\
\hline Entrepreneurial Motivation & 4.164 & 0.567 & 4.013 & 0.561 \\
\hline Entrepreneurial Personality & 4.122 & 0.614 & 4.075 & 0.747 \\
\hline Family Background & 4.434 & 0.558 & 3.565 & 0.614 \\
\hline Entrepreneurial Intention & 4.190 & 0.635 & 3.872 & 0.546 \\
\hline
\end{tabular}

Source : Questionnaire, 2018

\section{Multiple Regression}

According table 4 below, the multiple regression formula for this research can be written as follows: 


$$
Y=-0.060+0.202 X 3+0.683 X 4+E
$$

Where,

Y : Entrepreneurial Intention

$\mathrm{X} 1$ : Entrepreneurial Education

X2 : Entrepreneurial Motivation

X3 : Entrepreneurial personality

X4 : Family Background

Table 4 : Multiple Regression Data

\begin{tabular}{|c|c|c|c|c|c|c|}
\hline & & & Coefficients & & & \\
\hline \multicolumn{2}{|c|}{ Model } & \multicolumn{2}{|c|}{ Unstandardized Coefficients } & \multirow{2}{*}{$\begin{array}{c}\begin{array}{c}\text { Standardized } \\
\text { Coefficients }\end{array} \\
\text { Beta }\end{array}$} & \multirow[t]{2}{*}{$\mathrm{t}$} & \multirow[t]{2}{*}{ Sig. } \\
\hline & & B & Std. Error & & & \\
\hline \multirow{5}{*}{1} & (Constant) &,- 060 & 1,798 & &,- 033 & 973 \\
\hline & TEE & ,030 & 075 & 021 & ,399 & 690 \\
\hline & TEM & 060 & 083 & .047 & 717 & .474 \\
\hline & TEP & 202 & 089 & 160 & 2,259 & .025 \\
\hline & TFB & 683 & 093 & .550 & 7,340 & 000 \\
\hline
\end{tabular}

a. Dependent Variable: TEI

Source : Questionnaire, 2018

Based on table 4, researcher concluded that :

1. Entrepreneurial Education (TEE) $\mathrm{t}$ value is 0.690, this value is bigger than Alpha 0.05, which indicate that Entrepreneurial Education has not any significant. The beta coefficient value of this variable means that Entrepreneurial intention will increase by $3 \%$ for every one unit increase of Entrepreneurial Education.

2. Entrepreneurial Motivation (TEM) t value is 0.474 , this value is bigger than Alpha 0.05, which indicate that Entrepreneurial Motivation has not any significant. The beta coefficient value of this variable means that Entrepreneurial intention will increase by $6 \%$ for every one unit increase of Entrepreneurial Motivation.

3. Entrepreneurial Personality (TEP) is significantly influencing on the Entrepreneuraial Intention as it's coefficient of regression $=0.025$ is less than the $\alpha=0.050$. The beta coefficient value of this variable means that Entrepreneurial Intention will increase by $20.2 \%$ for every one unit increase of Entrepreneurial Personality.

4. Family Backgroud (TFB) is significantly influencing on the Entrepreneuraial Intention as it's coefficient of regression $=0.000$ is less than the $\alpha=0.050$. The beta coefficient 
value of this variable means that Entrepreneurial Intention will increase by $68.3 \%$ for every one unit increase of Family Backgroud.

\section{Hypothesis Testing}

\section{T-test}

Based on the table above (table 4), significance value of each independent variable on the dependent variable with significance level of 0.05 is shown.

a. Analysis of Entrepreneurial Education (X1) on Entrepreneurial Intention (Y) Ho1: There is no significant influence of Entrepreneurial Education on Entrepreneurial Intention

Ha1: There is significant influence of Entrepreneurial Education on Entrepreneurial Intention

Based on the table above, the result shows that t-count of Entrepreneurial Education is 0.399 and it is less than the t-table that should be at least 1.650. Furthermore, the tsignificance is 0.690 which is more than 0.05. As a result, Ho1 is accepted and Ha1 is rejected. Thus, partially Entrepreneurial Education does not significantly influence the Entrepreneurial Intention.

b. Analysis of Entrepreneurial Motivation (X2) on Entrepreneurial Intention (Y)

Ho2: There is no significant influence of Entrepreneurial Motivation on Entrepreneurial Intention

Ha2: There is significant influence of Entrepreneurial Motivation on Entrepreneurial Intention

Based on the table above, it shows that the t-count of Entrepreneurial Motivation is 0.717, in which it means the t-table (1.650) is greater than t-count (0.717). In addition, $\mathrm{t}$ significance of Entrepreneurial Motivation variable is 0.474 which is greater than the level of significance (0.05). As a consequence, Ho2 is accepted and Ha2 is rejected. Thus, partially Entrepreneurial Motivation has no significant influence on Entrepreneurial Intention.

c. Analysis of Entrepreneurial Personality (X3) on Entrepreneurial Intention (Y)

Ho3: There is no significant influence of Entrepreneurial Personality on Entrepreneurial Intention 
Ha3: There is significant influence of Entrepreneurial Personality on Entrepreneurial Intention

According to the table above, it states that the t-count of Entrepreneurial Personality is 2.259 , in which it is greater than the t-table. with value 1.650. Moreover, the tsignificance is 0.025 , it is less than the level of significance which is 0.05 . It results in the Ho3 is rejected and Ha3 is accepted. In conclusion, partially Entrepreneurial Personality has significant influence on the Entrepreneurial Intention.

d. Analysis of Family Background (X4) on Entrepreneurial Intention (Y)

Ho4: There is no significant influence of Family Background on Entrepreneurial Intention

Ha4: There is significant influence of Family Background on Entrepreneurial Intention

The result of the table above shows that the t-count of Family Background is 7.340 which is more than the t-table 1.650 value. Additionally, it also shows that Personal Values have tsignificance $(0.000)$ that is lower than the level of significance, which is 0.05 . These findings result in $\mathrm{Ho} 4$ is rejected and $\mathrm{Ha} 4$ is accepted. To sum it up, partially Family Background has significant influence on Entrepreneurial Intention.

\section{F-Test}

Table 5 : F-test

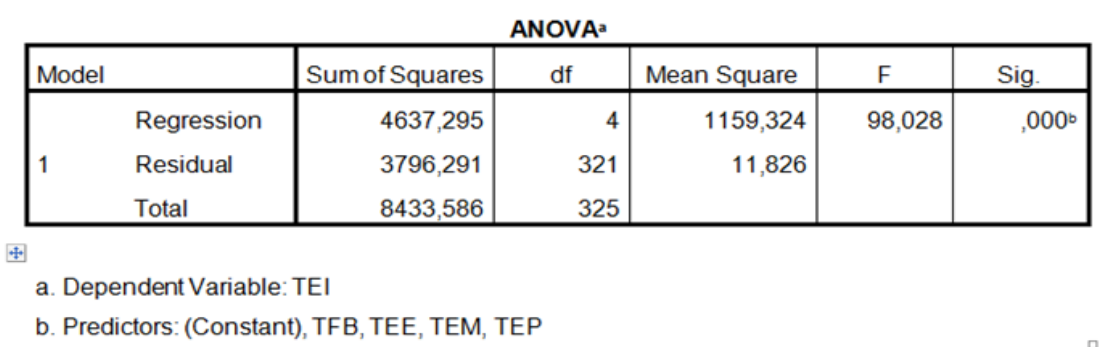

Source : Questionnaire, 2018

Ho5: There is no simultaneous significant influence of Entrepreneurial Education, Entrepreneurial Motivation, Entrepreneurial Personality, and Family Background on Entrepreneurial Intention 
Ha5: There is simultaneous significant influence of Entrepreneurial Education, Entrepreneurial Motivation, Entrepreneurial Personality, and Family Background on Entrepreneurial Intention

The F-Test above shows that fcount is 98.028 which is greater than the f-table with value 2.46. Furthermore, the f-value in this test is 0.000 , in which it is smaller than the significant value which is 0.000 . Hence, it means the Ha5 is accepted, and indicates all independent variables, which are Entrepreneurial Education (X1), Entrepreneurial Motivation (X2), Entrepreneurial Personality (X3), and Family Background (X4) do simultaneously have significant influence on the Entrepreneurial Intention.

\section{Coeficient Correlation}

Table 6 : Coeficient Correlation

\begin{tabular}{|l|r|r|r|r|r|}
\hline Model & R & R Square & $\begin{array}{c}\text { Adjusted R } \\
\text { Square }\end{array}$ & $\begin{array}{c}\text { Std. Error of the } \\
\text { Estimate }\end{array}$ & Durbin-Watson \\
\hline 1 &, $742^{\mathrm{a}}$ &, 550 &, 544 & 3,43896 & 1,672 \\
\hline
\end{tabular}
a. Predictors: (Constant), TFB, TEE, TEM, TEP
b. Dependent Variable: TEI

Source : Questionnaire, 2018

From the table 6 , the researcher would look at the correlation coefficient $(\mathrm{R})$ to interpret the relationship between variables. Based on the data, it shows the value of $\mathrm{R}$ is 0.742 or $74.2 \%$. Which is means that the correlation between all variables independent (Entrepreneurial Education, Entrepreneurial Motivation, Entrepreneurial Personality and Family Background) strong correlation between dependent variable (Entrepreneurial Intention). 
The contribution of independent variables (Entrepreneurial Education, Entrepreneurial Motivation, Entrepreneurial Personality and Family Background) to dependent variable are $54.4 \%$, while the rest $45.6 \%$ influenced by other variables outside of the study.

\section{Discussion}

The results showed that 2 non-significant variables were Entrepreneurial Education and Entrepreneurial Motivation. While 2 others significant variables are Entrepreneurial Personality and Family Background. But simultaneously, the independent variable (Entrepreneurial Education, Entrepreneurial Motivation, Entrepreneurial Personality and Family Background) significantly influences to the dependent variable (Entrepreneurial Intention). The results of this study are in accordance with the results of the study of Echecopar et all (2011) and Hisrich et al (2018).

\section{G. Recomendation}

Based on the resultof t-test, Family Background has the biggest contribution to Entrepreneurial Intention, for the government, they can pay serious attention to the family business, for the example forming associations with various positive goals such as giving information to one another to establish cooperation, technology development specifically related to online business, giving reguler training, promotion of products / services in a comprehensive manner so as to foster an entrepreneurial spirit among the next generation. Based on the result of PWC (2014) 95\% of business in Indonesis are family business, this data is huge potential that can be utilized by goverment in developing the economic climate in Indonesia.

University can pay more attention in designing curricula that related family business, giving special cources on "Family Business". In addition, Entrepreneurial Personality also contributued the second highest after Family Background, therefore the university can develop cuccirulum that inline to soft skills, to support entrepreneurial spirit among students, both as entrepreneurs in the future or as the corporate entrepreneurs.

Future researchers can add other variables that related to Entrepreneurial Intention, including Self Efficacy, Personal Traits, Goverment Policies, Subjective Norms, Perceived Behavior Control, Culture / Religious Affiliation and University Environment (Syamsudin et al, 2018). In 
Addition, increasing the number of respondents will give different results, as well as samplig, by taking samples in different places will produce the better data.

\section{References}

Ahmad, N.H., Ramayah, T., Wilson, C., and Kummerow, L. Is Entrepreneurial Competency and Business Success Relationship Contingent Upon Business Environment? A Studi of Malaysian SMEs. International Journal of Entrepreneurial Behaviour \& Research, 16(3), $2010: 182-203$.

Alain, Fayolle \& Benoit, Gailley. 2008. "From craft to science: Teaching models and learning processes in entrepreneurship education". Emerald Insight : Journal of European Industrial Training, Vol. 32(7) : 569-593.

Anderson Galvão, Joao J. Ferreira, Carla Marques, (2018) "Entrepreneurship education and training as facilitators of regional development: A systematic literature review", Emerald Insight : Journal of Small Business and Enterprise Development, 25 (1) : 17-40.

Bae, Tae Jun; Qian, Shanshan; Miao, Chao and Fiat, James O (2014). The Relationship between Entrepreneurship Education and Entrepreneurial Intentions: A Meta-Analytic Review. Baylor University.

Chen, Shuping; Chen, Xia ; Cheng, Qiang and Shevlin, Terry (2010). Are Family Firms more Tax Aggressive than Non-family Firms? Elsevier : Journal of Financial Economics. 91 (1) : 41-61.

Echecopar, German; Bustamante, Carla and Bejares , Consuelo (2011). Entrepreneurial Intentions and Activities of Students In Chile. Global University Entrepreneurial Spirit Students' Survey : Global Survey for Chile.

Fayolle, Alain \& Gailly, Benoit (2008) "From craft to science: Teaching models and learning processes in entrepreneurship education", Emeral Insight : Journal of European Industrial Training. 32 (7) : 569-593,

Hisrich, R. D., Peters, M. P., \& Sheperd, D. A (2018). Entrepreneurship. Tenth edition. New York : Prentice Hall.

Jaafar, Mastura \& Aziz, Abdul Rashid Abdul (2008) "Entrepreneurship education in developing country: Exploration on its necessity in the construction programme", Journal of Engineering, Design and Technology, Vol. 6 Issue: 2 : 178-189

Joseph, L. L. (2012). The Impact of Family Influence and Involovement On Career Development. University of Central Florida.

Kirkwood, Jodyanne (2009) "Motivational factors in a push-pull theory of entrepreneurship", Emerald Insight : Gender in Management: An International Journal, 24(5) : 346-364.

Malhotra, M.K. (2012). Operations Management,10th Edition. USA: Pearson

Maresch, Daniela; Harms, Rainer; Kailer, Norbert and Wurm, Birgit Wimmer (2016). The Impact of Entrepreneurship Education On The Entrepreneurial Intention of Students In Science and EngineeringVersus Business Studies University Programs. Elsevier : Technological Forecasting \& Social Change. 104 (2016) : 172-179.

McClelland, David C. (2010) .Entrepreneur Behavior and Characteristics of Entrepreneurs. The Achieving Society. New York : Cambridge University Press 
Nabi, Ghulam \& Linan, Fransisco. 2011. Graduate entrepreneurship in the developing world: intentions, education and development". Emerald Insight : Education + Training, Vol. 53(5) : 325-334.

Nabi, Ghulam ; Holden, Rick and Andreas Walmsley, (2006) "Graduate career-making and business start-up: a literature review", Emerald Insight : Education + Training, 48 (5) : 373-385

Ndofirepi, TM and Rambe, P (2016). The Entrepreneurial Orientation Of College Students In A Struggling Economy Context. Journal of Contemporary Management, Volume 13 : 13331367.

Nugraha, R. T. (2016). The Influence of Entrepreneurial Motivation and Entrepreneurial marketing Towards Business Success Of Textilles Entrepreneurs. Sumatera Utara University.

Ryan, Tomas, P. (2013). Sample Size Determination and Power. John Wiley and Sons.

Sesen, Harun (2013) "Personality or environment? A comprehensive study on the entrepreneurial intentions of university students", Emerald Insight : Education + Training, 55 (7) :.624-640

Shane , S \& Venkataraman, S (2000). Entrepreneurship as a field of research: The promise of entrepreneurship as a field of research. Academy of management review, 26 (1) : 13-17.

Stevenson, H.H., \& Jarillo, J.C. 1986. Preserving entrepreneurship as companies grow. Journal of Business Strategy, 6: 10-23.

Sumarsono, Sonny (2010). Entrepreneurship. Yogyakarta : Graha Ilmu.

Susilaningsih (2015). Pendidikan Kewirausahan Di Perguruan Tinggi : Pentingkah Untuk Semua Profesi ? Jurnal Economia 11(1)

Shamsudin, S. F., Mamun, A. A., Nawi, N. B., Nasir, N. A., \&amp; Zakaria, M. N.

(2017). Factors Affecting Entrepreneurial Intention Among The Malysian University Students. The Journal of Developing Areas, 51 : 424-431.

Ugwuja, Omeh Gabriel (2010). Influence Of Family background On The Academic Achievement Of Senior Secondary School Students In Nsukka Educational Zone Of Enugu State. Thesis : Universities of Nigeria Nsukka.

Wong, Matthew. A (2014). Entrepreneurial Culture: Developing a Theoretical Construct and its Measurement. Western University : Dissertation.

Yan, Jun (2010). The Impac of Entrepreneurail Personality Traits on Perception of New Venture Opportunity. Emerald Insight : New England Journal of Entrepreneurship 13 (2) : 21-35 